\title{
Note on a Sailfish (/stiophorus americanus Cuvier and Valenciennes) new to the British Fauna.
}

\author{
By
}

\section{J. R. Norman.}

[Published by permission of the Trustees of the British Museum.]

With 2 Figures in the Text.

Авочт 9 a.m. (flood tide) on 17th August,1928, a large sailfish was captured in a dying condition in the main channel of the Yealm estuary, South Devon, opposite the Yealm Hotel, about a mile above the Yealm Bar. The fish was carefully packed up by Mr. V. C. Wynne-Edwards, and promptly despatched to the British Museum (Natural History), where the plaster cast shown in the accompanying illustration (Fig. 1) was prepared by Mr. S. Stammwitz. The specimen was then cut into two pieces and preserved in alcohol.

Owing to the difficulty of preserving these large fishes in museums, except as stuffed skins, and to the marked changes which they appear to exhibit at different stages of growth, our knowledge of the group which includes the swordfishes, sailfishes, and spearfishes is decidedly limited, and the identification of species is a matter of some difficulty.*

In a recent monograph, $\dagger$ Jordan and Evermann distinguish nine species of Istiophorus, of which five are said to be new to science. The descriptions of four of these new species are based solely on photographs, the fifth being described from a plaster cast in the museum at Honolulu. As suggested by the authors themselves, some of the characters used by them in their key to the species may be "matters of age not indicating specific distinction." According to this key, the present specimen from Devonshire would appear to be referable to one of their new species-I. maguirei from the West Indies, but, so far as I am able to judge from the description and photograph, there seems to be no valid reason for separating this from $I$. americanus, which is found on the Atlantic coast of America from Brazil northwards to Cape Cod and beyond.

The first mention of the species in question, indeed, the first allusion to a sailfish, is to be found in Piso's Historia Rerum Naturalium Brasilia

* For a complete summary of our knowledge of the group up to that date, see Goode, Rep. U.S. Fish. Comm. (1880), 1883, pp. 289-386, pls. I-XXIV.

$\dagger$ Occ. Papers Calif. Acad. Sci., XII, 1926, 113 pp., 20 pls. 
... printed at Amsterdam in 1648. In this work a few lines of description and a crude but recognisable figure are given by Marcgrave (p. 171), who gives the fish the name of "Guebucu brasiliensibus." No species of this genus was systematically described until 1786, when Broussonet* published a description based on a specimen and a drawing made by Sir Joseph Banks, giving the fish the name of Scomber gladius. The type of this species, a stuffed skin eight feet in length, is preserved in the collection of the British Museum, and was said to have come from "La Mer des Indes." In 1802, Lacepède† established the genus Istiophorus for this species. In 1831, Cuvier and Valenciennest founded the species I. americanus on the figure in Piso and Marcgrave's work, and redescribed the Indian species as $I$. indicus, ignoring for some unknown reason Broussonet's earlier name. According to Cuvier and Valenciennes, I. americanus occurs also on the Atlantic coast of Africa, and they mention a specimen seven feet in length figured by Barbot, which had been caught off Commendo. This is the only reference $I$ have been able to trace of the species occurring on the eastern side of the Atlantic, unless the young specimen caught between France and the Cape of Good Hope, and described by Cuvier and Valenciennes§ as Histiophorus pulchellus, should prove to be identical with $I$. americanus.

Several authors have expressed doubt as to whether I. americanus is specifically distinct from I. gladius, and the two species were united by Günther and Lütken. No attempt has been made previously to compare specimens of similar size, and I take this opportunity of publishing a description of the specimen from Devonshire, and also of Broussonet's type specimen of $I$. gladius, which I regard as representing a distinct species.

Istiophorus americanus, Cuv. \& Val. (Figs. 1, 2).

Depth of body about $6 \frac{1}{2}$ in the length (from tip of sword to base of caudal), length of head nearly 3. Distance from tip of sword to anterior margin of eye about twice the length of rest of head; diameter of eye $3 \frac{1}{2}$ in postorbital part of head, interorbital width $1 \frac{3}{5}$. Sword narrow, regularly tapering, nearly twice as broad as deep, its upper and lower surfaces both rounded. Maxillary extending to a little beyond eye; jaws with bands of minute, conical teeth, which extend forward on to the lateral and ventro-lateral surfaces of the sword. Dorsal XXXV (+VIII), 7 ; the whole fin depressible into a deep groove which extends nearly to the origin of the soft dorsal; origin of spinous dorsal above operculum ; outline of fin irregular, the longest spines about middle of fin, $1 \frac{1}{3}$ in length of head ; last visible spine followed by eight short, stiff, stub-like spines,

* Mem. Acad. Sei., 1786, p. 454, pl. 10.

‡ Hist. Nat. Poiss., VIII, p. 293. $\dagger$ Hist. Nat. Poiss., III, p. 374.

$\S$ l.c., p. 305 . 
NOTE ON SAILFISH.

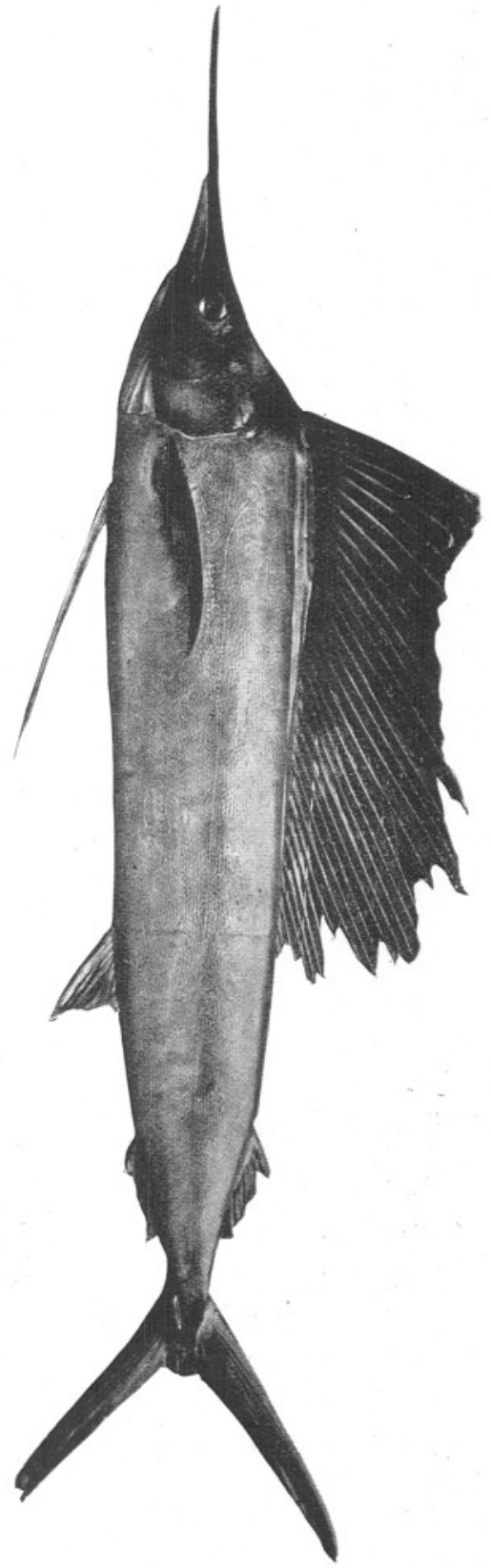

FIG. 1.-Plaster cast of specimen of Sailfish (Istiophorus americanus) from the Yealm Estuary, South Devon.

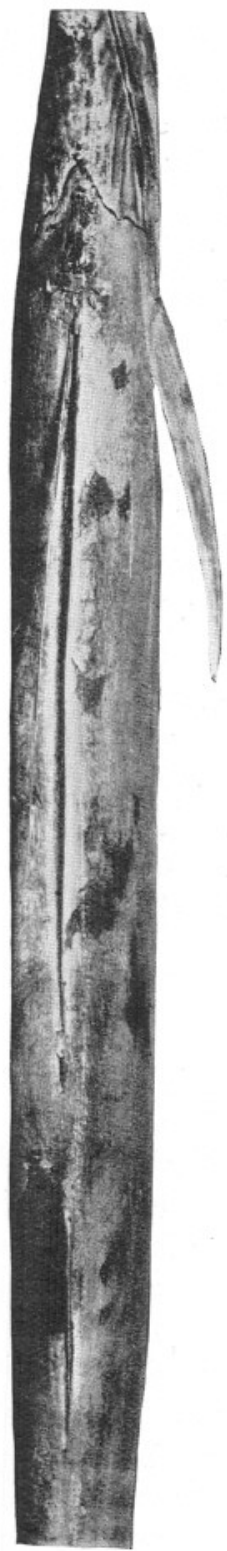

FIG. 2.-Ventral view of the fresh specimen, showing the groove for the reception of the pelvic fins. 
which are completely hidden in the groove, and decrease in size posteriorly; soft dorsal separated from the last stub-like spine by a distance which is a little greater than diameter of eye. Anal $9+7$; origin of first anal fin, which is depressible into a groove, below 33rd dorsal spine; origin of second anal about level with that of soft dorsal. Pectoral a little less than $\frac{1}{2}$ length of head. Pelvic slender, tapering, about $1 \frac{2}{5}$ in length of head, depressible into a deep groove which extends backwards nearly to the vent (Fig. 2). Upper lobe of caudal $1 \frac{3}{5}$ in length of head. Caudal peduncle with two strong, parallel keels on either side. Brownish above, silvery grey below; all the fins greyish brown, the spinous dorsal with a number of small, round, dark spots on the membrane between the spines.

The principal dimensions of the specimens are as follows :-

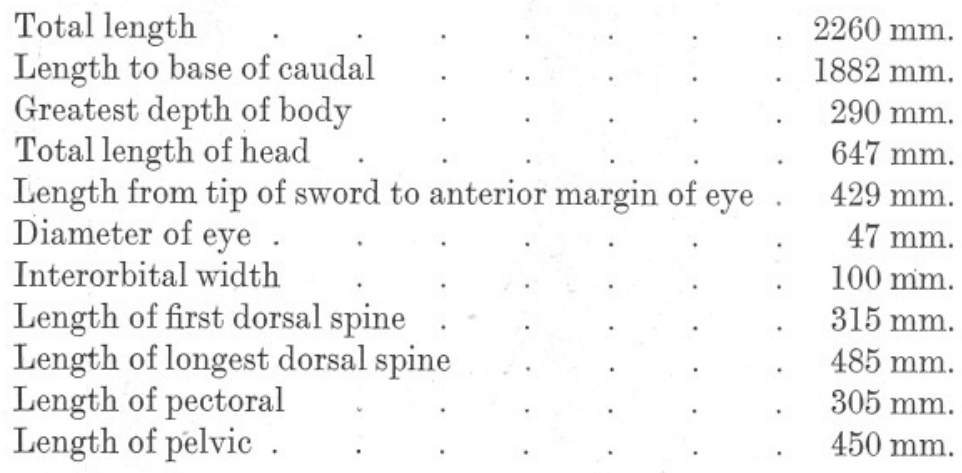

\section{Istiophorus gladius (Broussonet).}

Depth of body 6 or 7 times in the length, length of head nearly 3 . Distance from tip of sword to anterior margin of eye nearly $2 \frac{1}{2}$ times the length of rest of head; diameter of eye $3 \frac{1}{2}$ in postorbital part of head, interorbital width $1 \frac{2}{3}$. Sword and teeth similar to those of $I$. americanus. Dorsal XLV, 7 ; origin of spinous dorsal above operculum; outline of fin apparently irregular, the longest spines about middle of fin, longer than head; all the spines are visible, and decrease gradually in length posteriorly ;* origin of soft dorsal separated from last spine by a distance which is little greater than diameter of eye. Anal 14 (or 13) +7 ; origin of first anal fin below 35th dorsal spine ; origin of second anal about level with that of soft dorsal. Pectoral about $\frac{1}{2}$ length of head. Pelvic slender, tapering, $1 \frac{1}{4}$ in length of head. Upper lobe of caudal nearly $1 \frac{1}{2}$ in length of head. Caudal peduncle with two strong, parallel keels on either side.

* The depth of the grooves for the reception of the fins, and the extent to which the posterior dorsal spines are hidden, is not apparent in this stuffed skin. 
The principal dimensions of the specimen are as follows :-

\begin{tabular}{|c|c|c|c|c|}
\hline Total length & . & . & . & . $2458 \mathrm{~mm}$. \\
\hline Length to base of caudal & . & & . & $2058 \mathrm{~mm}$. \\
\hline Greatest depth of body & . & & ${ }^{\circ}$ & $270 \mathrm{~mm}$. \\
\hline Total length of head. & . & . & . & $705 \mathrm{~mm}$. \\
\hline Length from tip of sword to al & anterio & pr marg & of eye & $500 \mathrm{~mm}$. \\
\hline Diameter of eye. . . & . $\quad$. & . . . & . & $50 \mathrm{~mm}$. \\
\hline Interorbital width & . & . & . & $90 \mathrm{~mm}$. \\
\hline Length of first dorsal spine & . & . & . & $345 \mathrm{~mm}$. \\
\hline Length of highest dorsal spine & he & . & . & $820 \mathrm{~mm}$. \\
\hline Length of pectoral . & . & & & $356 \mathrm{~mm}$. \\
\hline Length of pelvic . & . & . & . & $520 \mathrm{~mm}$. \\
\hline
\end{tabular}

This species differs from I. americanus chiefly in the longer sword, larger spinous dorsal fin, with higher posterior rays, longer anal fin, and in the longer pelvics. 
